PRZEGLĄDY - POLEMIKI - MATERIAEY

Kwartalnik Historyczny Rocznik CXXVIII, 2021, 2 PL ISSN 0023-5903

\author{
DARIUSZ ADAMCZYK \\ https://orcid.org/0000-0001-5917-5532 \\ Niemiecki Instytut Historyczny, Warszawa
}

\title{
REPLIKA NA TEKST WŁADYSŁAWA DUCZKI \\ SREBRO PIERWSZYCH PIASTÓW. UWAGI W ZWIĄZKU Z KSIĄŻKĄ DARIUSZA ADAMCZYKA*
}

Władysław Duczko, omawiając moją książkę Srebro i władza. Trybuty i handel dalekosiężny a kształtowanie się państwa piastowskiego i państw sąsiednich w latach 800-1100, stawia tezy, które nie znajdują odzwierciedlenia w faktach. Ponieważ zarazem zniekształcają one kreślony przez niego obraz treści monografii, należy się do nich odnieść. Argumentacja archeologa oscyluje między dwiema osiami: etnicznej przynależności deponujących kruszec w tzw. epoce wikingów oraz chronologizacji i zawartości skarbów srebrnych w Polsce Centralnej, zwłaszcza Wielkopolsce.

Recenzent konstatuje, że „zwyczaj deponowania był praktykowany wszędzie tam, gdzie przebywali Szwedzi i inni Skandynawowie, i należy widzieć w nim postępowanie silnie osadzone w bardzo długiej tradycji" (s. 360). Sugeruje tym samym, że głównie, jeśli nie wyłącznie Skandynawowie zakopywali srebro i złoto. Jeszcze bardziej karkołomna jest teza, że „nic nie wskazuje na to, aby Słowianie w Europie Wschodniej praktykowali deponowanie kruszcu" (s. 361). Przytoczone w mojej pracy tabele (np. nr 36, s. 71-72) obalają te wywody. Aby nie pozostać gołosłownym, wystarczy wskazać na najstarsze depozyty z dirhemami, które występowały na obszarach zamieszkanych przez słowiańskie grupy archeologicznie przyporządkowywane kulturom romneńsko-borszewskiej czy wolyncewskiej (proszę nie mylić z tzw. kulturą wołyńską) w dorzeczu Psiołu, Oskołu, Sejmu, Desny oraz górnej Oki i Donu, gdzie obecność Skandynawów nie jest potwierdzona przed X w. (a w wypadku osady

* W. Duczko, Srebro pierwszych Piastów. Uwagi w związu z książką Dariusza Adamczyka, KH 127, 2020, 2, s. 355-367. 
Supruty nad Upą przed końcem IX stulecia). Wymieńmy te najważniejsze, w miarę dobrze zbadane znaleziska dirhemów: Zawaliszino 809/810, „Gorochow” 811/812 (ponad 2 tys. monet), Niżnyje Nowoselki 811/812, Niżnaja Syrowatka 812/813, Kremlewskoje 812/813, Łapotkowo 816/817, Kozielsk 815/816, Nowotrojckoje 818/819, Jarylowiczi 820/821 ${ }^{1}$. Ewidencja jest przytłaczająca, tak że nie trzeba chyba w tym miejscu wymieniać dalszych.

Uszczypliwy zarzut Duczki, jakoby autor pracy Srebro $i$ władza wydawał się nie wiedzieć, że „przed XI w. nie ma ozdób, które mogliśmy przypisać" Słowianom wschodnim (s. 361) jest kolejnym nieporozumieniem. W osadach archeologicznych kultur wolyncewskiej i romneńskiej znajdowana jest różnego rodzaju biżuteria, w tym naszyjniki. W ufortyfikowanej osadzie Nowotrojckoje nad środkowym Psiołem, istniejącej w IX w., odkryto - obok tygli i matryc do przerobu kruszcu - ozdoby należące do miejscowej ludności słowiańskiej (również fragmenty biżuterii chazarsko-alańsko-bułgarskiej typu Sałtow-Majaki i staro-madziarskiej kultury subotickiej). Natomiast skarb srebrnych ozdób z Iwachnik nad Sułą (ok. 830-840) zawierał m.in. naszyjniki utrzymane w stylu zarówno grupy wolyncewskiej, jak i romneńskiej. Wystarczy zapoznać się z badaniami Iwana Ljapuszkina (Ivan Lâpuškin) czy Aleksieja Komara (Aleksej Komar) $^{2}$.

Przejdźmy do chronologii depozytów z Polski Centralnej. Na wstępie sprostujmy następujące twierdzenie Duczki: „Ta niewyczerpująca tematu prezentacja powodów chowania skarbów i ich związku ze zwyczajami skandynawskimi była konieczna, gdyż w monografii Adamczyka nie znajdujemy szczegółowego omówienia dyskusji nad problematyką przyczyn i okoliczności deponowania kruszcu. Autor mógłby odnieść się do dysputy prowadzonej w nauce polskiej" (s. 360). o faktach się nie dyskutuje, więc odsyłam do rozdziału o stanie badań we wspomnianej monografii na stronach 17-21, który archeolog przemilcza.

Natomiast dowolność argumentacji Duczki bez podania konkretów pojawia się w całej ostrości w twierdzeniu, że autor tych słów,

${ }^{1}$ Ich kontekstualizację czytelnik znajdzie w mojej nowo wydanej monografii pt.: Monetarisierungsmomente, Kommerzialisierungszonen oder fiskalische Währungslandschaften? Edelmetalle, Silberverteilungsnetzwerke und Gesellschaften in Ostmitteleuropa (800-1200), Wiesbaden 2020, s. 13-16.

2 I.I. Lâpuškin, Slavâne Vostočnoj Evropy nakanune obrazovaniâ drevnerusskogo gosudarstva (VIII - pervaâ polovina IX v.), Leningrad 1968, s. 146-147, 153; A.V. Komar, Ivahnikovskij klad (Vremâ sokrytiâ i kul'turnyje svâzi kompleksa), „Stratum Plus. Archaeology and Cultural Anthropology” 2017, 5, s. 113-131; idem, Polâne i Severâne, „Drevnejšie Gosudarstva Vostočnoj Evropy" 2012, s. 128-191. 
„powtarzając za archeologami [--] datuje pojawienie się pierwszych skarbów w środkowej Polsce na lata trzydzieste X w., nie przejmując się ich niekompletnym stanem zachowania" (s. 362). Duczko kontynuuje: „Daty pojawienia się skarbów w obrębie domeny piastowskiej nie można jeszcze uznać za ustaloną. Aktualny stan badań pozwala widzieć ją raczej bliżej połowy dziesiątego stulecia niż wcześniej” (s. 362). Niestety nie podaje on źródeł aktualnego stanu badań, nonszalancko ignorując trud uaktualnienia i uzupełnienia inwentarzy skarbów z ziem polskich przeprowadzony przez sztab polskich numizmatyków i jednego badacza z Niemiec ${ }^{3}$. Logiczny błąd polega z kolei na tym, że jeśli fragmentaryczność składu skarbów nie pozwala na ich precyzyjne datowanie (s. 365), to skąd wywodzi Duczko ich chronologię na połowę X w.?

Według najnowszych danych najstarsze znane nam depozyty z Polski Centralnej, określone na podstawie najmłodszych występujących w nich monet, to Kalisz-Piwonice 934/935, Ochle 936/937, Dębicz 936/9374, Iłów-Miękinki 937/938 i Obra I 941-943. Kompozycja chronologiczna ich dirhemów jest stosunkowo zwarta, odpowiadając generalnie strukturze skarbów rosyjsko-ukraińskich; pozwala więc założyć, że dotarły one na Mazowsze i do Wielkopolski krótko po ich emisji. Poza tym: nawet gdyby Duczko miał rację i powyższe znaleziska należałoby datować ok. 950 r., nie do końca jest jasne, jaki efekt poznawczy dla tematu monografii Srebro i władza miałoby przesunięcie ich chronologii o 10-15 lat. Czy Skandynawowie zaczęli masowo pojawiać się w Polsce w połowie X w.? I to oni mieliby „zaszczepić” Słowianom obyczaj deponowania srebra (niosąc swoistego rodzaju tezauryzacyjny kaganek oświaty)? To zakrawa na zwykłą kazuistykę ${ }^{5}$.

Natomiast rację ma Duczko, że w monografii Srebro $i$ władza nie uwzględniono kruszcu niemonetarnego. Podyktowane to było faktem zrozumienia współzależności między napływem dirhemów, niemieckich denarów i anglosaskich pensów na ziemie polskie, a ekonomią polityczną

${ }^{3}$ Frühmittelalterliche Münzfunde aus Polen. Inventar, t. 1-5, red. M. Bogucki, S. Suchodolski, P. Ilisch, Warszawa 2011-2017.

${ }^{4}$ Skarb z Dębicza był pierwotnie datowany na ok. 950 r., jest on więc dobrym przykładem, że uaktualnienie chronologii może działać również wstecz.

${ }^{5} \mathrm{Na}$ marginesie dodajmy, że nie do końca słuszne jest twierdzenie o braku skarbów w dziesiątowiecznych Czechach (s. 359). W przeciwieństwie do monetarnej mozaiki w polskich znaleziskach, czeskie depozyty są bardzo jednorodne i zawierają głównie monety miejscowe, w mniejszym stopniu bawarskie. Por. L. Polanský, The 10th century Bohemian deniers in the light of revised finds, w: Money Circulation in Antiquity, the Middle Ages and Modern Times. Time, Range, Intensity, red. S. Suchodolski, with the collab. of M. Bogucki, Warsaw-Cracow 2007, s. 127-152, zwłaszcza mapa na s. 129. 
powstającej monarchii piastowskiej w X i XI stuleciu (do sytuacji monetarnej w XI w. archeolog się nie odnosi) w szerokiej perspektywie geograficznej. Należy tu dodać, że ujęcie opisanego procesu jako części składowej inter- i transkontynentalnych interakcji od IX w. wypełnia lukę nie tylko w polskiej historiografii. Obecność metali szlachetnych w formie ozdób, sztabek czy tzw. placków, podobnie jak ich bardzo wysoki stopień fragmentaryzacji, świadczą raczej o obiegu wewnętrznym w obrębie danej społeczności. Temat ten poruszam w nowszych publikacjach ${ }^{6}$.

Uwzględniając argumenty przedstawione w niniejszej replice, tezy Duczki nie wytrzymują krytyki, a apodyktyczne stwierdzenie o niezrealizowaniu przez piszącego te słowa celów badawczych jest na podstawie jego wywodów nie do zaakceptowania.

Biogram: dr hab. Dariusz Adamczyk, historyk w Niemieckim Instytucie Historycznym w Warszawie oraz wykładowca na Uniwersytecie Leibniza w Hanowerze. W centrum jego naukowych badań znajdują się m.in. historia pieniądza, procesy państwotwórcze w Europie Wschodniej, numizmatyka; kontakt: adamczyk@dhi. waw.pl.

Author: Dr hab. Dariusz Adamczyk, historian at the German Historical Institute Warsaw and lecturer at the Leibniz University of Hannover. His research interests focus on, among other things, history of money, state-building processes in Eastern Europe, and numismatics; contact: adamczyk@dhi.waw.pl.

${ }^{6}$ D. Adamczyk, Monetarisierungsmomente, s. 179-212; idem, Obieg srebra $w$ czasach Mieszka I. Fiskalizm czy ekonomia prestiżu?, w: Rzecz niepospolita. Przedmiot jako symbol statusu, władzy i funkcji, red. M. Saczyńska, E. Wółkiewicz [w druku]. 